\title{
A multi-model approach to understanding the role of Pacific sardine in the California Current food web
}

\author{
Isaac C. Kaplan ${ }^{1, *}$, Tessa B. Francis ${ }^{2}$, André E. Punt ${ }^{3}$, Laura E. Koehn ${ }^{3}$, \\ Enrique Curchitser ${ }^{4}$, Felipe Hurtado-Ferro ${ }^{3}$, Kelli F. Johnson ${ }^{3}$, \\ Salvador E. Lluch-Cota ${ }^{5}$, William J. Sydeman ${ }^{6}$, Timothy E. Essington ${ }^{3}$, \\ Nathan Taylor ${ }^{7}$, Kirstin Holsman ${ }^{8}$, Alec D. MacCall ${ }^{6}$, Phillip S. Levin ${ }^{9}$ \\ ${ }^{1}$ Conservation Biology Division, Northwest Fisheries Science Center, National Marine Fisheries Service, NOAA, \\ 2725 Montlake Blvd E, Seattle, WA 98112, USA \\ ${ }^{2}$ University of Washington Tacoma, Puget Sound Institute, Tacoma, WA 98421, USA \\ ${ }^{3}$ School of Aquatic and Fishery Sciences, University of Washington, Seattle, WA 98195-5020, USA \\ ${ }^{4}$ Department of Environmental Sciences, Rutgers University, 14 College Farm Road, Room 243, New Brunswick, NJ 08901, USA \\ ${ }^{5}$ Centro de Investigaciones Biológicas del Noroeste, S.C., 23096 La Paz, BCS, Mexico \\ ${ }^{6}$ Farallon Institute, 101 H Street, Suite Q, Petaluma, CA 94952, USA \\ ${ }^{7}$ Pacific Biological Station, Fisheries and Oceans Canada, 3190 Hammond Bay Rd, Nanaimo, BC V9T 6N7, Canada \\ ${ }^{8}$ Alaska Fisheries Science Center, NOAA Fisheries, 7600 Sand Point Way NE, Building 4, Seattle, WA 98115, USA \\ ${ }^{9}$ School of Environmental \& Forest Sciences, University of Washington, Box 351200, Seattle, WA 98195, USA
}

\begin{abstract}
We develop a multi-model approach to explore how abundance of a forage fish (Pacific sardine Sardinops sagax) impacts the ecosystem and predators in the California Current, a region where sardine and anchovy Engraulis mordax have recently declined to less than $10 \%$ of contemporary peak abundances. We developed or improved applications of 3 ecosystem modeling approaches: Ecopath, Model of Intermediate Complexity for Ecosystem assessment (MICE), and Atlantis. We also used Ecopath diets to predict impacts to predators using a statistical generalization of the dynamic Ecosim model (Predator Response to the Exploitation of Prey [PREP]). Models that included brown pelican Pelecanus occidentalis at the species level (MICE and Ecopath/PREP) both predict moderate to high vulnerability of brown pelicans to low sardine abundance. This vulnerability arises because sardine comprises a large fraction of their diet, and because other important prey (anchovy) also exhibit large population fluctuations. Two of the ecosystem models (MICE and Atlantis) suggest that California sea lions Zalophus californianus exhibit relatively minor responses to sardine depletion, due to having broader diets and lower reliance on another fluctuating species, anchovy. On the other hand, Ecopath/PREP suggests that sardine declines will have a stronger impact on California sea lions. This discrepancy may in part reflect structural differences in the models: Atlantis and MICE explicitly represent density dependence and age-structure, which can mitigate effects of prey depletion in these models. Future work should identify fisheries management strategies that are robust to uncertainties within and among models, rather than relying on single models to assess ecosystem impacts of management and forage fish abundance.
\end{abstract}

KEY WORDS: Forage fish $\cdot$ Pacific sardine $\cdot$ California Current $\cdot$ Ecosystem model $\cdot$ California sea lion $\cdot$ Brown pelican $\cdot$ Multi-model approach

${ }^{*}$ Corresponding author: isaac.kaplan@noaa.gov

${ }^{\S}$ Advance View available online April 17, 2018
() The authors 2019. Open Access under Creative Commons by Attribution Licence. Use, distribution and reproduction are unrestricted. Authors and original publication must be credited. 


\section{INTRODUCTION}

Ecosystem-based fisheries management (EBFM) is broadly accepted by scientists, managers, stakeholders, and policymakers as a necessary approach to the conservation and management of marine natural resources (Pikitch et al. 2004). A key feature of EBFM is the acknowledgement of uncertainty in coupled environmental-ecosystem processes, as well as of the potential impacts of human activities, including fisheries, on the ecosystem (Link et al. 2012, Thorpe et al. 2015). Decision-makers need tools that can evaluate a range of possible policies, given uncertainties in both ecology and human behavior. A priority in implementing EBFM, therefore, is the development of analytical tools to support analyses of tradeoffs in ecological and socio-economic factors (Patrick \& Link 2015, Collie et al. 2016). Climate and weather modeling has shown the value of using multiple quantitative models to forecast and to understand system behavior. Because models have different assumptions about system dynamics, the multi-model approach can illuminate key areas of uncertainty in ways that support decision-making (Marasco et al. 2007, Thorpe et al. 2015, Ianelli et al. 2016, Jacobsen et al. 2016).

A central issue in EBFM is the tradeoff between harvest of forage fish (e.g. sardines, herring, anchovies, sensu Smith et al. 2011) and potential impacts on dependent predators. Pikitch et al. (2014) estimate a value of global forage fish harvest of $\sim$ US\$5.6 billion, but this is exceeded by their supportive value of $\sim$ US $\$ 11.3$ billion as prey for harvested predators (not accounting for the value of nonharvested, protected species). The potential tradeoffs between harvest of forage fish and abundance of predators have been a focus of global, empirical analyses (Cury et al. 2011), previous multi-model approaches (Smith et al. 2011), an international task force (Pikitch et al. 2012), and eco-labelling guidelines (Marine Stewardship Council 2014). Nonetheless, these efforts have limitations, and the modeling efforts have met some challenges for at least 2 reasons. First, in some instances, the modeling syntheses either relied heavily on a single model framework (e.g. Pikitch et al. 2014), or utilized multiple model frameworks but noted strong discrepancies between them (Smith et al. 2011). Second, ecosystem models readily available for these global syntheses were not necessarily tailored to address forage-fish management, and may suffer from perils of 'recycling' models for new purposes (Essington \& Plagányi 2014). For example, a 2013 fisheries management workshop on the US west coast found that 'available ecosystem models are not sufficiently well developed to form the basis for an evaluation of the impact of sardine control rules on broader ecosystem impacts' (Pacific Fishery Management Council 2013, p. 19). In this case, no existing model satisfied detailed criteria needed by managers regarding geographic extent, inclusion of international fisheries, validation using hindcasts, and complex and realistic dynamics of sardine and harvest management rules.

Recent declines in forage fish in the California Current in the USA have spurred the need for better information on ecosystem response to forage fish fluctuations and fishing. Fortunately, this system has a long history of ecosystem approaches to forage fish management. Almost $40 \mathrm{yr}$ ago, management plans explicitly recognized tradeoffs between harvest and the needs of predators (Pacific Fishery Management Council 1978). Two key forage stocks, Pacific sardine Sardinops sagax and northern anchovy Engraulis mordax (henceforth sardine and anchovy), are important prey sources for harvested species such as salmon Oncorhynchus spp. and albacore tuna Thunnus alalunga, protected species such as humpback whale Megaptera novaeangliae, and numerous species of protected seabirds (Szoboszlai et al. 2015, Koehn et al. 2016). Sardine and anchovy have fluctuated strongly in abundance over the past 500$1700 \mathrm{yr}$ (Baumgartner et al. 1992, McClatchie et al. 2017), and recently both species have declined to less than $10 \%$ of contemporary peak abundances (Hill et al. 2015, MacCall et al. 2016, Thayer et al. 2017). This has led to the closure of a sardine fishery valued at US\$21 million in 2012, and has raised concerns regarding effects on predators and the broader ecosystem (though Zwolinski et al. 2017 suggest early signs of an increase in anchovy stock biomass in 2016). Predators in the Southern California Bight may be particularly affected by a lack of forage fish, because sardine and anchovy abundances can be high in this region, but at times decline to very low levels. For example, breeding failure of the once endangered brown pelican Pelecanus occidentalis has occurred in the Southern California Bight in recent years (Henry 2015), and poor foraging conditions have been linked to very low weight of California sea lion (Zalophus californianus) pups (McClatchie et al. 2016) and subsequent mortality events.

Motivated by the need to better understand the impacts of the most recent declines in forage species, in this paper we present a multi-model evaluation of the impact of sardine depletion on these predators in the California Current food web. The models were tailored for this purpose within an interdisciplinary working group setting, including modelers and local 
managers, other technical experts on the ecosystem, and stakeholders (Ocean Modeling Forum, http:// oceanmodelingforum.org/). We adopt a multi-model approach to better understand effects of structural uncertainty in the models, because previous studies illustrated that predictions are strongly influenced by decisions about spatial resolution, taxonomic resolution, diets, and functional feeding responses (Fulton et al. 2003b, Pinnegar et al. 2005, Gårdmark et al. 2013). Therefore, we search for results that are consistent across models, and also identify reasons for divergence in model predictions. Though our models center on sardine, which have constituted the bulk of forage fish landings off the USA in recent decades, our approach sets sardine in the context of the broader forage base.

\section{METHODS}

\subsection{Overview of models}

To explore how sardine abundance impacts the California Current ecosystem and predators, we developed or improved applications of 3 ecosystem modeling approaches: Ecopath, a Model of Intermediate Complexity for Ecosystem assessment (MICE), and Atlantis (Fig. 1, Table 1; Supplement 1 at www. int-res.com/articles/suppl/m617p307_supp. pdf). These approaches are described in more detail below but, in general, we employed models that differ in complexity, breadth, and accessibility, i.e. the amount of time required to build and run them.

The Ecopath model (Koehn et al. 2016) is static and therefore cannot project future dynamics, but is taxonomically complex, and provided essential information about diet composition, predation mortality rates, and predator reliance on various forage species. The MICE (Plagányi et al. 2014) is a spatially explicit, multi-species model (Punt et al. 2016) focused on sardine, anchovy, other forage fish, and 2 predators. The MICE allowed extensive sensitivity tests to be conducted and used Monte Carlo approaches to quantify uncertainty. The MICE also leveraged information assembled by Koehn et al. (2016) for the Ecopath model. The more complex Atlantis ecosystem model (Kaplan et al. 2017, Marshall et al. 2017) focused on strategic risk to the broader food web and ecosystem. Atlantis considers impacts of sardine abundance on a wider range of predators than the
MICE, includes 2-way trophic coupling (impacts of prey on predators and vice versa), and includes broad indirect trophic effects on competitors and prey of sardine.

In addition to these 3 new model applications, for context we compared results to 2 previously developed approaches: (1) the Predator Response to the Exploitation of Prey (PREP) equation (Pikitch et al. 2012), a generalized set of predictions based on 10 dynamic food web models (Ecosim; Christensen \& Walters 2004), as a rough approximation of the impacts to predators that might be expected in Ecosim, given California Current Ecopath diets; and (2) the Supportive Role to Fishery ecosystems (SURF) index (Plagányi \& Essington 2014), which identifies forage species likely to have large ecosystem-level effects.

Each of these ecosystem modeling approaches has costs and benefits associated with its use in providing management guidance. For example, the cost of the more complex Atlantis model is the lack of full sensitivity tests and stochasticity such as those included in the MICE model (Plagányi et al. 2014). Below we compare these ecosystem modeling approaches, detail the methodology for each, and identify robust conclusions from the models as well as reasons for divergence.

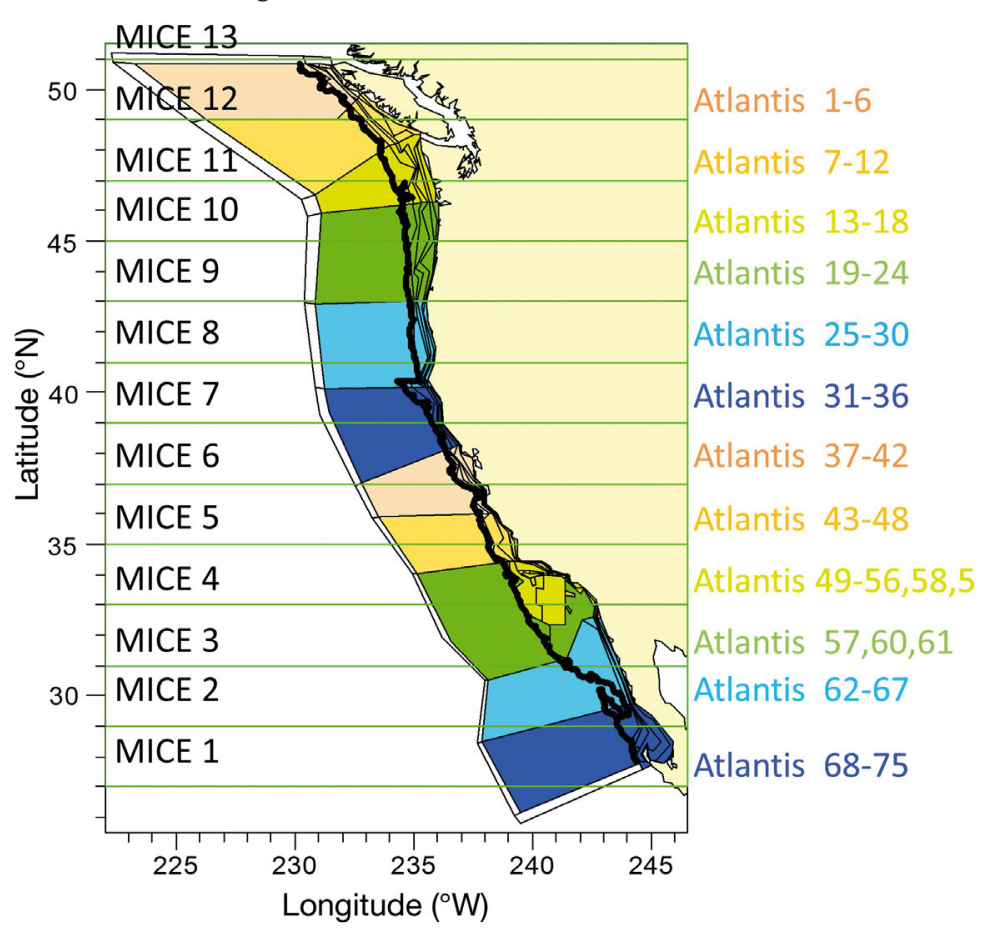

Fig. 1. Model domains for 3 California Current ecosystem models. Model of Intermediate Complexity for Ecosystem assessment (MICE) regions $1-13$ are demarcated per $2^{\circ}$ of latitude from $27-53^{\circ} \mathrm{N}$ (green lines). Atlantis model polygons are colored and demarcated by thin black lines. Ecopath model domain is inshore of the $2000 \mathrm{~m}$ isobaths (thick black line) 
Table 1. Modeling approaches considered for this study. Diet fractions are the mean from 500 balanced models selected from Monte Carlo draws (Ecopath), year 1 diets (Atlantis), or average over a 2000 yr simulation without fishing (Model of Intermediate Complexity for Ecosystem assessment [MICE]). '-' indicates a descriptor that is not applicable

\begin{tabular}{|c|c|c|c|}
\hline Model & Ecopath & MICE & Atlantis \\
\hline Functional groups & 92 & $\begin{array}{l}\text { Sardine, anchovy, } \\
\text { other forage fish, sea lions, } \\
\text { brown pelicans }\end{array}$ & $\begin{array}{l}\text { 78, including sardine, anchovy, } \\
\text { sea lions, pelagic-feeding } \\
\text { seabirds }\end{array}$ \\
\hline Spatial resolution & None & 13 latitudinal zones & 89 spatial areas \\
\hline Dynamic? (i.e. project through time) & No & Yes & Yes \\
\hline Recruitment regimes & - & $\begin{array}{l}\text { Based on stock assessment } \\
\text { output and environmentally } \\
\text { driven; anchovy recruitment } \\
\text { also influenced by sardine }\end{array}$ & $\begin{array}{l}\text { Base case from stock-recruit } \\
\text { curve; also tested forcing of } \\
\text { sardine and anchovy with MICE } \\
\text { output }\end{array}$ \\
\hline Representation of harvest & $\begin{array}{l}\text { Static } \\
\text { fishing } \\
\text { rates }\end{array}$ & $\begin{array}{l}\text { Included US and Canadian } \\
\text { sardine fisheries, and Mexican } \\
\text { sardine fishery off northwest } \\
\text { coast of Baja California } \\
\text { peninsula }\end{array}$ & $\begin{array}{l}\text { Constant fishing mortality rates } \\
\text { on forage fish and other har- } \\
\text { vested species }\end{array}$ \\
\hline Sardine \% in sea lion diet & 12 & 12 & 47.4 \\
\hline Anchovy \% in sea lion diet & 2.8 & 2.8 & 0.2 \\
\hline Sardine $\%$ in brown pelican diet & 26 & 26 & - \\
\hline Sardine $\%$ in pelagic-feeding seabird diet & - & - & 15.9 \\
\hline Anchovy \% in brown pelican diet & 64 & 64 & - \\
\hline Anchovy \% in pelagic-feeding seabird diet & - & - & 0.1 \\
\hline
\end{tabular}

\subsection{Ecopath model (diets and predator mortality fractions)}

Ecopath (Christensen \& Walters 2004) and its dynamic version Ecosim are frequently used in EBFM studies to evaluate possible trophic impacts of management actions (Christensen \& Maclean 2011). The Ecopath food-web model used here was developed for the California Current region from northern Vancouver Island, BC, to Punta Eugenia, Baja California, Mexico, and extending offshore to the $2000 \mathrm{~m}$ isobath (Koehn et al. 2016) (our Fig. 1). Key aspects of the model are summarized in Table 1, with additional model characteristics provided in Supplement 1. This model has 92 functional groups. There is high taxonomic resolution of forage fish and forage-fish predators, meaning that most are modeled as individual species, or aggregated into functional groups with only a few species of similar life history and ecological characteristics. Diet information for forage fish predators mainly was taken from the California Current Predator Diet Database (Szoboszlai et al. 2015). Diet information from government documents and theses was also used for predators with little or no diet information in the California Current Predator
Diet Database. Diet data were first assigned to region (Canada, Washington, Oregon, California, or Baja California) and then aggregated to the level of the whole model domain, weighted by the abundance of the predator in each region (see Koehn et al. 2016 for information on diets for individual predators). The proportion of forage-fish mortality caused by each predator (predator mortality fraction) was determined using information from the model on consumption, diets, and predator abundance.

\subsection{MICE}

MICE are relatively simple multi-species models that are structured to focus on the main management questions under consideration and include properties that advance their use as tools for ecosystem assessment (Plagányi et al. 2014). The MICE developed for the California Current Ecosystem (Punt et al. 2016) includes 3 forage species (sardine, anchovy, and 'other forage') and 2 predator species (brown pelicans and California sea lions). Key aspects of the model are summarized in Table 1, with additional model characteristics in Supplement 1. The model also in- 
cludes an 'other prey' group. It is spatially structured (Fig. 1) and has 48 time-steps within each year for the prey species; the time-step for the predators is annual. The MICE considers the impacts of changes in prey biomass on predator reproductive and survival rates, but does not consider the impact of predation on prey (primarily because the modeled predators do not constitute a large proportion of natural mortality for the prey species, Koehn et al. 2016). Sardine is the only species in the MICE model that is targeted by fisheries, including fisheries in 3 countries (Mexico, the USA, and Canada). The catches by the USA and Canada fisheries are based on the harvest control rules in place for those countries and the catches off Mexico are determined using a constant harvest rate.

The parameters of the MICE model are determined based on fits to available data or assessment outputs or set using literature values. Specifically, the stockrecruitment relationships for sardine and anchovy are based on outputs from Hurtado-Ferro \& Punt (2014) and MacCall et al. (2016), with the stockrecruitment relationship for sardine driven by the environment and that for anchovy also dependent on the biomass of sardine. Although there is still no generally accepted mechanism of sardine-anchovy interaction (see MacCall 2009), the estimates of historical anchovy abundance developed by MacCall et al. (2016) show a clear downward shift following 1990 when sardines became abundant. We speculate that the presence of sardines offshore may constrain the distribution of anchovies, preventing offshore expansion. The result is higher spawning densities of anchovies (which have been observed), implying higher rates of density dependence due to filter-feeding cannibalism (see MacCall 1990). Process error is accounted for in the generation of recruitment of sardine, anchovy, and 'other forage', such that for sardine, the simulated extent of variation in biomass in the absence of exploitation matches the variation observed in historical scale deposits in the Santa Barbara Basin, and for anchovy, the simulated frequency of zero recruitment matches that in MacCall et al. (2016). The relationship between the reproductive rate for brown pelicans and the biomass of prey is parameterized using data on reproductive rates of brown pelican at 2 sites in the Southern California Bight (see Punt et al. 2016, their Fig. A.8).

A baseline scenario was used to conduct 100 simulations of $1000 \mathrm{yr}$ each, or a total of 100000 simulated years. These simulations included effects of fisheries and environmentally driven recruitment on sardines and link brown pelican and California sea lion reproductive success to forage availability. Punt et al.
(2016) consider a broader set of simulations that explore sensitivity to assumptions regarding diet, migrations, recruitment dynamics of forage fish, effects of forage availability on predator survival, and strength of the links between forage and predator reproductive rates. However, the key results from Punt et al. (2016) are evident in the baseline scenario, which is the focus here.

\subsection{Atlantis model}

The Atlantis framework (Fulton et al. 2011) is an end-to-end model (Travers et al. 2007, Rose et al. 2010) that includes oceanography, food web dynamics, nutrient cycling, and fisheries, in a spatially explicit domain. It has been applied to over a dozen ecosystems globally (Fulton et al. 2011). Earlier versions of the Atlantis model for the California Current have been used to explore the impacts on predators of depleting an aggregated forage fish group (Kaplan et al. 2013), without explicitly modeling sardine, anchovy, or other small pelagic fish at the species level.

Key aspects of the model applied here are summarized in Table 1, with additional model characteristics in Supplement 1. This application includes population dynamics and spatial distributions of 5 primary producer groups, 25 benthic and planktonic invertebrates, 36 fish groups, 10 marine mammal groups, 2 bird groups, and 2 detritus categories (Kaplan et al. 2017, Marshall et al. 2017). This includes population dynamics and spatial distributions of sardine, anchovy, herring, and an aggregated group of 'other forage' fish, California sea lions, and an aggregated pelagic-feeding seabird group. The latter group includes brown pelicans, but is parameterized primarily to represent the common murre Uria aalge and Cassin's auklet Ptychoramphus aleuticus, which are more omnivorous than pelicans, with greater consumption of mesozooplankton, particularly euphausiids (Sydeman et al. 1997, Abraham \& Sydeman 2006). Diets were parameterized from literature similar to that used to parameterize Ecopath (and MICE), but with some differences stemming from interpretation and model dynamics as noted in Table 1 and Supplement 1. Similar to the MICE, sardine and anchovy are treated as each being a single stock on the US west coast. Unlike the MICE, however, recruitment of sardine, anchovy, and other fish is derived from Beverton-Holt relationships with no process error. Mammal and bird reproduction is based on a fixed number of offspring per adult per year (e.g. 1 fledgling per year per adult bird). Declines in the 
availability of sardine or other forage will force predators in Atlantis to switch prey if alternative prey are available. If no alternative prey are available, predator growth and resulting size-at-age decreases, and in extreme cases this also reduces fecundity.

Fishing mortality in the Atlantis model is constant at year 2013 rates $\left(\mathrm{yr}^{-1}\right)$, and therefore is not based on a harvest control rule like the MICE. For sardine only, fishing was concentrated on the continental shelf (0-200 m depth) near 6 major ports, to capture potential areas of local depletion. Specifically, sardine fishing was applied in model polygons focused on 6 fishing regions: Ensenada, Southern California, Central California, Oregon, Washington, and British Columbia (see Kaplan et al. 2017, their Fig. 1). Fishing mortality on sardine was uniform within a fishing region (typically 3 model polygons). Fishing for all other fleets (groundfish, crab, etc.) was distributed uniformly across the model domain. Atlantis includes much detail on trophic interactions, oceanography, and spatial resolution, but at the cost of relatively long simulation times. Therefore, the scenarios presented here project 2013 initial conditions forward for $50 \mathrm{yr}$, using fishing to drive sardine abundance to stable levels as a way of exploring the impacts of sardine depletion on predators. Sardine fishing mortality rates were scaled to $0,0.5,1,2,4$, and 8 times the initial (2013) rates, for a total of 6 simulations.

\subsection{Context from PREP equation and SURF index}

We compared and contrasted results from our models to predictions from the PREP equation and the SURF index. These 2 models use diet information from the Ecopath model (Koehn et al. 2016), but PREP focuses on predator response and SURF focuses on identifying prey species likely to have large ecosystem-level effects.

The PREP equation (Pikitch et al. 2012) is a statistical generalization of the Ecosim predator response to forage fish declines. We apply it here because we lack an updated Ecosim model for the California Current (though Field 2004 and Field et al. 2006 developed Ecosim models simulating food web dynamics of the California Current based primarily on data from the 1990s and 1960s). The PREP equation generalizes results from 10 Ecosim models, and was originally intended as an approximation for regions that lack quantitative ecosystem models. Here, we apply the PREP equation to approximate the response that might be expected from Ecosim. The PREP equation predicts the percent decline in predator abundance
$(R)$ as a function of predator diet dependence on forage fish $(D)$ and relative depletion of the forage fish $\left(B / B_{0}\right)$, with fitted model parameters $\rho$, $\alpha$, and $\beta$ from statistical regressions that are specific for broad predator taxonomic groups (birds, mammals, and fish):

$$
R=\rho D^{\alpha}\left(1-\frac{B}{B_{0}}\right)^{\beta}
$$

The dependence parameter $D$ was assumed equal to the diet fraction represented by forage fish in the diets of California sea lion and brown pelican as given by the diet data in Ecopath. We applied the PREP equation to predict the impacts of relative sardine abundance $\left(B / B_{0}\right)$ on sea lions and brown pelicans. Sardine abundance levels were selected to match the levels of relative abundance in the Atlantis simulations. Generic values for $\alpha$ and $\beta$ for birds from Pikitch et al. (2012) were applied to brown pelicans, and values for mammals were applied to California sea lions. PREP is only relevant for direct consumers of sardine (i.e. it cannot estimate indirect effects on prey or competitors of sardine). In our multi-model framework, PREP results provide a statistical prediction of what might be expected from a suite of Ecosim models that are similar to Atlantis, in the sense of being dynamic representations of a full food web, but differ in crucial assumptions regarding age structure and density dependence (Walters et al. 2016).

The SURF index (Plagányi \& Essington 2014) identifies species whose depletion might lead to large ecosystem-level effects. The SURF index is based on diet contribution of each species to all predators. Here we used the Ecopath-model diet fractions. Essentially, the SURF index is a weighted measure of food web connectivity, where the weights scale with diet fraction. Higher scores $(>0.001)$ indicate greater potential for large indirect food web effects stemming from depletion of a specific forage species. This method relies only on knowledge of the number of links in the food web and the diet proportions, and is generally robust to the degree of taxonomic resolution in the diet information (Plagányi \& Essington 2014). The results, summarized below and presented in more depth in Koehn et al. (2016), set the stage for the more complex models by suggesting which prey are most influential in the food web and would therefore be candidates for focus or inclusion in the other models.

\subsection{Model comparisons and common currency}

To effectively compare ecosystem models, it is important to identify how they overlap in formulation 
and structure, what information is shared among them, and how they differ. This is particularly important in our case study, where collaboration among modelers and empiricists led to consensus on some approaches and divergence on others; hence these models are not independent, but are intertwined, as is often the case in adaptive modeling processes for complex environmental problems (i.e. Fulton et al. 2015). The comparison between models (Table 1 and Supplement 1) should be kept in mind when interpreting results. The models differ in terms of the number of species included and the level of aggregation of those species. The latitudinal extent of the Ecopath, MICE, and Atlantis models was similar (Fig. 1), although Atlantis had higher spatial resolution than MICE, and Ecopath has no explicit spatial structure and excluded the area offshore of the $2000 \mathrm{~m}$ isobath. Seasonal migration of sardine in both the MICE and Atlantis models was parameterized based on the modeling of Parrish (Richard Parrish pers. comm., summarized in Punt et al. 2016, their Appendix A.1.1.1 and Figs. A.2 \& A.3). Diet assumptions were forced to be equivalent in MICE and Ecopath; the Atlantis model had a higher percentage of sardine in sea lion diets. Critically, the Atlantis model did not represent brown pelicans specifically, but aggregated their biomass and prey habits into a broader 'pelagic-feeding seabird' functional group, which has a lower consumption of sardine $(<16 \%)$ than brown pelicans in the MICE and Ecopath models and negligible consumption of anchovy $(<1 \%)$.

Given that the models differ in several respects, it is necessary to first define a 'common currency' to compare their outputs. Sardine biomass is an effective and logical common currency for the MICE and Atlantis models. Sardine biomass, and therefore availability as prey, is likely to drive predator survival and reproduction (in MICE and Atlantis) and growth (in Atlantis). The Atlantis simulations explore ecosystem impacts of 6 levels of sardine biomass (resulting from simulations based on different fishing mortality rates) ranging from 3000 to 3.7 million tons (Fig. 2). The MICE explored the impacts of the harvest control rule on sardine biomass through simulation with process error. To compare the estimated impacts of sardine fishing between Atlantis and the MICE, sardine biomass was used to 'assign' each of the 100000 simulated years from the MICE to the 6 Atlantis sardine abundance levels (Fig. 2). For example, the MICE predicts that $13 \%$ of years will have very low sardine abundance $(<26000$ tons), akin to the lowest level of abundance from the 6 Atlantis simulations. The most common level of sardine abun-

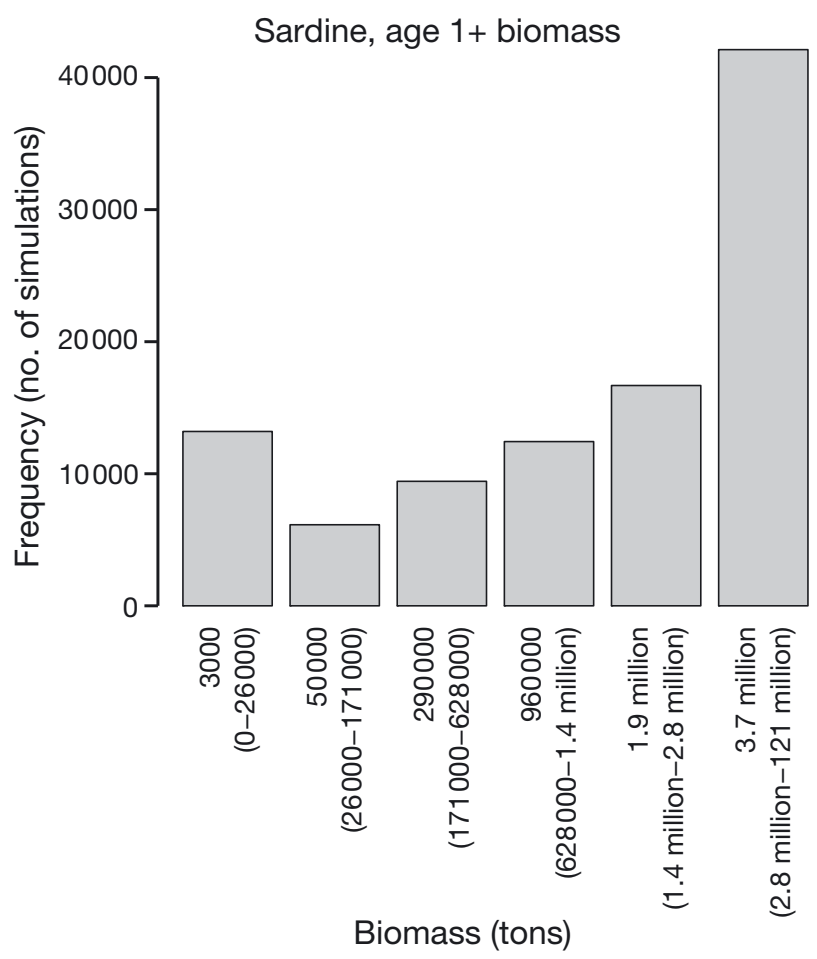

Fig. 2. Translating the Model of Intermediate Complexity for Ecosystem assessment (MICE) outputs into levels of sardine biomass comparable to Atlantis biomass projections. The $y$-axis is the frequency of simulated years in the MICE, out of 100000 , that fall within each level of Atlantis sardine biomass (indicated on $x$-axis by midpoint and range). Midpoints of the sardine biomass ranges correspond to Atlantis sardine biomass at the end of $50 \mathrm{yr}$ projections under various levels of sardine fishing ranging from 0 to 8 times the 2013 sardine fishing mortality rates

dance predicted by the MICE is $>2.8$ million tons, corresponding to unfished biomass in Atlantis. One difference between the models is that Atlantis predicts unfished levels near 3.7 million tons, and in a few rare cases, the biomass in the MICE reached 121 million tons. This is strong support for focusing on predator biomass or abundance response to forage biomass, rather than attempting to use common currencies based on sardine biomass relative to unfished biomass, a notoriously difficult metric for pelagic stocks with strong climate influences (A'mar et al. 2009).

In contrast to Atlantis and the MICE, the PREP equation applies Ecopath diets to predict predator response to the relative abundance of forage, which cannot be precisely converted to absolute sardine biomass. We therefore compared the magnitudes of impacts predicted by PREP across a range of relative sardine abundance to compare the outputs of the PREP equation and those of the other models. 


\section{RESULTS}

\subsection{Diet information in Ecopath}

We used Ecopath to identify predators to focus on in the other models, with a final emphasis on California sea lions and brown pelicans. Note that results reported here summarize figures and data in Koehn et al. (2016); our intent is to primarily discuss the role of this model within our suite of models. The Ecopath model indicated that predators with the largest proportions of sardine in their diets were brown pelican, halibut, and sea lions (both California and Steller, but heavily weighted towards California sea lion because of their larger biomass in the system), all with sardine as $>10 \%$ of their diet (average from 500 balanced models from Monte Carlo draws; see Koehn et al. 2016, their Fig. 2 and Appendix A). Predators causing the highest fractions of sardine mortality (predator mortality fractions) were humpback whales, sea lions, and hake Merluccius productus, each causing $>10 \%$ of sardine total mortality (on average) (see Koehn et al. 2016, their Fig. 3). Sea lions and brown pelican subsequently became the focus of the MICE and Atlantis models because they are central-place foragers that likely have enhanced vulnerability to changes in prey abundance because of restricted foraging ambits while breeding. In addition, the predator with the highest diet contribution of anchovy was brown pelican, with anchovy constituting $>60 \%$ of their diet. The substantial representation of both anchovy and sardine in brown pelican diets is notable because of the recent decline of brown pelican breeding success in the Southern California Bight (Henry 2015) coinciding with declines in sardine and anchovy. Other than these central-place foragers, Ecopath diets of halibut (14\% sardine and $8 \%$ anchovy on average) and dolphins (4\% sardine and $4 \%$ anchovy on average) indicate potential dependence on these forage fish, as discussed in the context of Atlantis results below.

\subsection{Context from SURF index}

The SURF index and the proportion of consumer biomass index (Smith et al. 2011) were calculated for each forage fish species in the Ecopath model. SURF values that exceed 0.001 and proportion of consumer biomass values that exceed 0.05 indicate that a dynamic food web model would likely predict that these are 'key' forage groups (i.e. indirect impacts on other species from fishing these species, Plagányi \&
Essington 2014). For this Ecopath model, no species alone had index values above these thresholds (see Koehn et al. 2016, their Fig. 5). However, when forage fish were aggregated (specifically sardine and anchovy, herring Clupea pallasii and anchovy, and sardine and herring), both sardine/anchovy and herring/anchovy had SURF values above 0.001 . Therefore, the SURF index, based upon the Ecopath model, suggests that low abundance of sardine alone may not lead to extensive ecological consequences, but depletion of multiple forage fish may (Koehn et al. 2016), providing further support for including anchovy in the other models.

\subsection{Impacts on brown pelicans}

Overall, the MICE and PREP equation were in agreement that declines in sardine abundance would lead to declines on average of brown pelican abundance, with PREP predicting stronger effects than the MICE. Atlantis did not include detailed representation of brown pelican, and its 'pelagic-feeding seabird' group was less reliant on sardine and anchovy and, therefore, had little response to their declines.

Specifically, the MICE predicted that brown pelican average abundance would be $29 \%$ lower when sardine biomass was at the lowest level $(<26000$ tons $)$ versus the highest (>2.8 million tons) (Fig. 3). It is important to note that these are average levels of pelican abundance and that the MICE model projections include individual years with low pelican abundance that occur at most levels of sardine biomass (lefthand tails in Fig. 3). Brown pelican decline by $>10 \%$ when sardine biomass falls below 171000 tons (the upper limit of the sardine abundance bin centered on 50000 tons in Fig. 2). In Supplement 2 (see Figs. S1-S3 at www.int-res.com/articles/suppl/m617p307_supp. pdf), we explored other metrics of impacts of sardine abundance on predators in the MICE, but these metrics were less responsive or similar to the responses in predator abundance.

PREP also predicted declines in brown pelican abundance, but of stronger magnitude compared to effects in the MICE (Fig. 4). At the lowest levels of sardine abundance, brown pelican were predicted by PREP to decline by $50 \%$, and even moderate sardine declines, i.e. $50 \%$ relative abundance, were predicted by PREP to lead to substantial declines in pelicans $(27 \%)$.

Structural differences between the Atlantis and MICE models likely influenced the predicted sensitivity of seabirds to sardines (Fig. 5). Specifically, the 


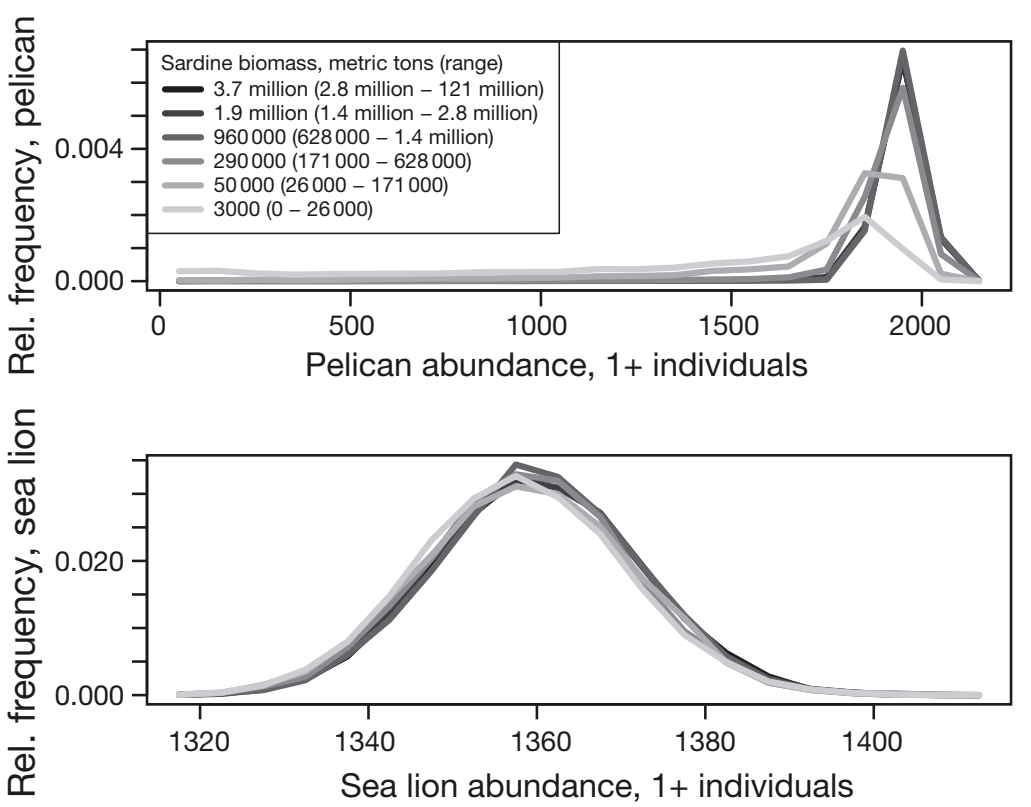

Fig. 3. Relative frequency of Model of Intermediate Complexity for Ecosystem assessment (MICE)-projected brown pelican abundance (top) and sea lion abundance (bottom) for 6 ranges of sardine biomass. MICE estimates were binned into sardine biomass ranges that match Atlantis outputs. Frequencies of estimated predator abundance are relative to all years for which projected sardine biomass fell within that range. Note in top panel the overlap of darkest lines (sardine biomass at 3.7 million, 1.9 million, and 960000 metric tons), and also that average pelican abundance shifts more $(29 \%)$ than the mode of abundance

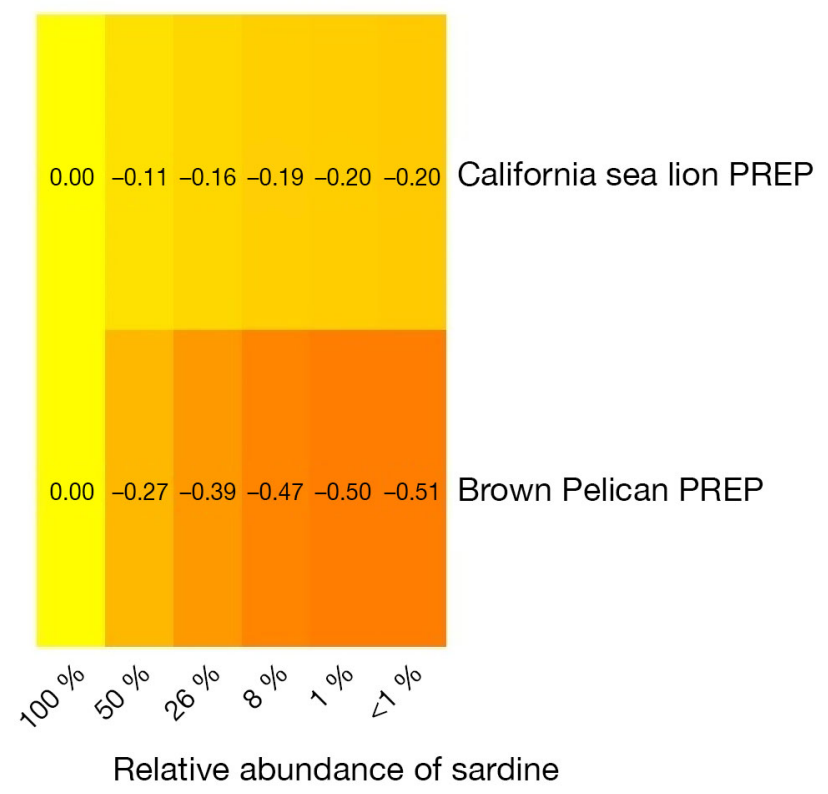

Fig. 4. Average expected decline in biomass of 2 sardine predators, as predicted by Predator Response to the Exploitation of Prey (PREP) based on diets from Ecopath (Koehn et al. 2016). 'Relative abundance of sardine' is percent of maximum sardine abundance. We use these percentages because they match the relative sardine biomass from Atlantis (as in Fig. 2). Text and color scale (yellow $=$ no change and red $=100 \%$ decline) within each cell indicate the relative change in predator biomass
Atlantis model contains an aggregated functional group (pelagic-feeding seabird), which included brown pelicans but was dominated by auklets and murres. The latter species are less reliant on, and therefore less sensitive to sardine, so that the aggregate group showed modest responses to sardine depletion. In contrast, the MICE explicitly modeled brown pelican, finding high sensitivity when sardine abundance was low. Thus, despite sharing a common currency (biomass), differences in the model structure make direct comparisons challenging.

\subsection{Impacts on California sea lions}

The MICE and Atlantis were in agreement that declines in sardine were likely to have minimal impact on California sea lions; PREP predicted declines for sea lions, but less than the declines predicted for brown pelicans. Declines in California sea lion abundance were $<1 \%$ in the MICE and $3 \%$ in Atlantis, at the lowest level of sardine biomass $(<26000$ tons $)$ compared to the highest (Figs. $3 \& 5$ ). The stochastic results from the MICE provide some insight into uncertainty around these declines: for 100000 simulated years, sea lion abundance in this model had a low coefficient of variation $(1 \%)$ and never fell below $97 \%$ of mean values.

PREP predicted up to $20 \%$ declines in sea lions, compared to the $50 \%$ declines in brown pelicans (Fig. 4). Even moderate sardine declines, i.e. $50 \%$ relative abundance, were predicted by PREP to lead to substantial declines in sea lions $(11 \%)$.

\subsection{Impacts on additional species (Atlantis)}

Atlantis identified predators that were not the focus of the MICE, but that may be candidates for future MICE models or for additional monitoring during the present regime of low sardine and anchovy abundance. Atlantis predicted that large piscivorous flatfish (including California halibut Paralichthys californicus) and dol- 


\begin{tabular}{|c|c|c|c|c|c|c|}
\hline 0.00 & -0.50 & -0.74 & -0.92 & -0.99 & -1.00 & Sardines \\
\hline 0.00 & 0.00 & 0.00 & 0.00 & 0.00 & 0.00 & California sea lion MICE \\
\hline 0.00 & -0.01 & -0.02 & -0.03 & -0.03 & -0.03 & California.sea.lions \\
\hline 0.00 & 0.00 & 0.01 & -0.01 & -0.10 & -0.29 & Brown Pelican MICE \\
\hline 0.00 & -0.03 & -0.04 & -0.04 & -0.04 & -0.04 & Seabirds..pelagic.feeders. \\
\hline 0.00 & -0.14 & -0.20 & -0.24 & -0.25 & -0.26 & Large.piscivorous.flatfish \\
\hline 0.00 & -0.06 & -0.12 & -0.19 & -0.23 & -0.24 & Dolphins \\
\hline 0.00 & -0.04 & -0.06 & -0.07 & -0.08 & -0.08 & Seabirds..benthic.pelagic.feeder \\
\hline 0.00 & -0.03 & -0.05 & -0.06 & -0.07 & -0.07 & Migrating.birds \\
\hline 0.00 & 0.00 & 0.00 & -0.01 & -0.01 & -0.01 & Baleen.whales \\
\hline 0.00 & 0.07 & 0.08 & 0.07 & 0.07 & 0.07 & Small.demersal.sharks \\
\hline 0.00 & 0.05 & 0.07 & 0.09 & 0.10 & 0.11 & Myctophids \\
\hline 0.00 & 0.03 & 0.04 & 0.06 & 0.06 & 0.06 & Small.planktivorous.fish \\
\hline 0.00 & -0.03 & -0.04 & -0.06 & -0.06 & -0.06 & Crangon.shrimp \\
\hline 0.00 & 0.07 & 0.11 & 0.14 & 0.15 & 0.16 & Pteropods \\
\hline 0.00 & 0.04 & 0.06 & 0.08 & 0.09 & 0.09 & Mesozooplankton \\
\hline 0.00 & 0.74 & 1.36 & 2.00 & 2.33 & 2.42 & Microzooplankton \\
\hline 0.00 & -0.09 & -0.13 & -0.16 & -0.18 & -0.18 & Pelagic.bacteria \\
\hline 0.00 & -0.04 & -0.06 & -0.07 & -0.07 & -0.07 & Coccolithophore \\
\hline 0.00 & -0.06 & -0.09 & -0.11 & -0.11 & -0.12 & Small.phytoplankton \\
\hline 0.00 & -0.03 & -0.05 & -0.06 & -0.06 & -0.06 & Labile.detritus \\
\hline & $0^{n}$ & مَ & & & ${ }_{3} 0^{\circ}$ & \\
\hline
\end{tabular}

Fig. 5. Average relative change in biomass or 1+ abundance of species from Atlantis and the Model of Intermediate Complexity for Ecosystem assessment (MICE) (respectively), grouped into distinct levels of sardine abundance ('Sardine biomass' axis corresponding to bars in Fig. 2). Comparisons are made with respect to the scenario with no fishing on sardines in the Atlantis model (left-hand column). Text and color scale (from blue $=$ most positive to red $=$ most negative) within each cell indicates the relative change in terms of numbers of age 1+ individuals (MICE) or biomass (Atlantis). The 2nd and 4th rows are results from MICE (black rectangles; California sea lions and brown pelicans), and all other results are from Atlantis. Sardine abundance from Atlantis is provided both in absolute terms ('Sardine biomass' axis) and relative terms (top row)

phins would decline if sardine abundance dropped and that these effects may be evident at relatively high abundances of sardine (i.e. $20 \%$ declines in large piscivorous flatfish and dolphins when sardine biomass fell below 1.4 million and 628000 tons, respectively; Fig. 5). Also, with relatively modest declines in sardine, Atlantis predicted 5-8\% declines in migrating seabirds (primarily sooty shearwaters Puffinus griseus) and benthic and pelagic-feeding seabirds (primarily cormorants and gulls). This decline was driven by diet compositions of $16 \%$ sardine for the migrating bird group and $5 \%$ for the benthic and pelagic-feeding bird group. Atlantis also predicted inverse relationships between sardines and their prey (e.g. zooplankton) and competitors (e.g. myctophids).

\section{DISCUSSION}

\subsection{Lessons learned: ecology}

A primary aim of this study was to identify consistent conclusions regarding sardines and dependent predators across models. We find that the 2 models that included brown pelicans (at the species level) predict high sensitivity of brown pelicans to low sardine abundance. A third model did not identify brown pelicans at the species level. This sensitivity is due, in part, to brown pelicans' limited diet breadth and preference for prey species that naturally undergo wide fluctuations in abundance. We also find that the predicted sensitivity of California sea lions varied across models. The 2 ecosystem models (MICE and 
Atlantis) that have age-structure and density dependence predict very minor dependency compared to the Ecopath-based PREP equation. Further, because California sea lions have broader diets than brown pelicans, the dynamic models suggest that sea lions have stable alternate prey options that buffer them from strong effects of sardine depletion.

Our modeling efforts were guided by local fishery managers' need for more information on consequences of sardine abundance for predators (Pacific Fishery Management Council 2013). However, our results here and as detailed previously (Koehn et al. 2016, Punt et al. 2016, Kaplan et al. 2017) suggest the important role of anchovy and other forage species, though not yet in a manner that facilitates standardized comparisons across models. For instance, based on the Ecopath diets, we found that the SURF index of prey importance was high for summed anchovy + sardine (Koehn et al. 2016). In the MICE, we tested 2 alternate scenarios regarding the mix of anchovy and sardine in predator diets (Punt et al. 2016); overall, the results suggested that doubling consumption of sardine and proportionally decreasing consumption of anchovy and other species increased the probability of pelican population collapse from $1 \%$ to $8 \%$. In Atlantis, we tested alternate scenarios involving levels of anchovy recruitment (Kaplan et al. 2017) and also plotted predator response relative to summed anchovy and sardine biomass. That paper also indicated an important role for myctophids, which increased in scenarios with low sardine abundance and appeared to stabilize the overall forage base (sardine, anchovy, herring, small planktivorous fish, and myctophids); note that myctophids are not represented explicitly in the MICE. Together, these multiple modeling efforts suggest a portfolio of forage species that transfer energy from lower trophic levels to dependent predators (Miller et al. 2010, Ruzicka et al. 2012), rather than indicating sardine as a single critical link in the food web.

\subsection{Lessons learned: structural uncertainty}

Our multi-model effort here is admittedly a comparison of models that differ substantially (Table 1 ; Supplement 1), though we have attempted to standardize outputs to common currencies, to share data among modelers, and to represent similar perturbations, i.e. levels of sardine depletion. Due to these differences, it is difficult to definitively attribute divergences in model behavior to specific aspects of the models, as has been done more formally elsewhere using nested models (e.g. Holsman et al. 2016). Nonetheless, our set of differing models illustrates the effects of structural uncertainty (i.e. the implications of different assumptions about functional forms and parameterization; Link et al. 2010, 2012, Payne et al. 2016). This aspect of uncertainty has often been poorly handled, particularly in larger end-to-end models (Plagányi 2007), despite evidence that model structure can strongly influence results, for instance via representation of mortality and predation (Fulton et al. 2003a).

In our work, divergent results between models stem in part from structural uncertainty due to (1) choices about taxonomic resolution, and (2) representation of population dynamics. Taxonomic resolution in Atlantis was insufficient to make detailed predictions regarding brown pelicans (which were aggregated with more abundant pelagic-feeding seabirds), limiting the utility of Atlantis in this case. An illustration of structural uncertainty stemming from representation of population dynamics is the Atlantis and MICE prediction that a sardine decline will have a weak impact on California sea lions, compared to stronger impacts predicted by the PREP equation (a generalization of Ecosim models). Stronger responses in Ecosim have been observed in previous comparisons of Ecosim and Atlantis for this region (Kaplan et al. 2013) and in global analyses of forage fish and predators (Smith et al. 2011), and are likely attributable to the explicit representation of density dependence and age-structure in Atlantis and the MICE, which buffers the system response (Walters et al. 2016). The case study presented here also suggests that the MICE tailored to this system has behavior more similar to Atlantis than to the PREP equation, despite the identical (Ecopath) diet information used to parameterize PREP and the MICE.

The impact of forage fish declines on predators has been addressed by other efforts including metaanalysis and modeling (Cury et al. 2011, Smith et al. 2011, Pikitch et al. 2012), but addressing structural uncertainty will continue to be important in this arena. Taxonomic resolution of the models (such as the brown pelican example above) is an often overlooked but important aspect of structural uncertainty. For instance, Forrest et al. (2015) noted that differences in predictions from Atlantis versus Ecosim for models of the continental shelf and slope off New South Wales, Australia were driven by differences in taxonomic aggregation as well as diet information. Structural uncertainty also relates to the directionality and extent of coupling between model compo- 
nents. For example, models of Baltic Sea cod Gadus morhua callarias that included feedbacks from lower trophic levels led to more stable cod dynamics and less sensitivity to assumptions about future climate than did models that were driven primarily by cod recruitment (Gårdmark et al. 2013). Similarly, Woodworth-Jefcoats et al. (2015) found divergent declines in catch between species-based and size-based foodweb projections of climate change impacts on central North Pacific fish species that they attributed to differences in model estimates of the relative strength of bottom-up or top-down controls. Given the potential for climate impacts on sardine and other pelagic stocks in the California Current (Cheung et al. 2015, Checkley et al. 2017), such analyses in our region will necessitate exploration of both 2-way coupling (e.g. in Atlantis) and 1-way coupling (e.g. MICE, in which prey affect predators but not vice versa). Overall, we expect that structural uncertainty must be addressed and understood, but that 'the solution is to look for management actions that are robust to the uncertainty in model structure... The strength lies in that these conclusions [from multiple models] are indeed general, as they are valid independent of whether we are using a simple single-species biomass model or a full food-web model... Thus, successful management of exploitation no longer becomes a question of which model to rely on, but which management actions should be taken based on common knowledge from all available models' (Neuenfeldt 2014, p. 68; with reference to Gårdmark et al. 2013).

\subsection{Lessons learned: multi-model approaches}

Our results emphasize that EBFM often requires a suite of models with distinct characteristics, rather than a single model that fits a checklist of criteria. Considering the characteristics of Ecopath, MICE, and Atlantis (Table 1; Supplement 1, including Table S1), the models were constructed to have similar (but not identical) model domains and treatment of fishery catch and diet data, and a nested taxonomic scope. All models accounted for uncertainty and were validated, but in manners specific to each model. Beyond the common characteristics of the models, divergence was quite useful and allowed models to complement one another. For instance, the Ecopath is a relatively simple static, non-spatial representation of the food web, but this meant that it could be deployed rapidly, could inform the MICE diets and taxonomic scope, and was amenable to
Monte Carlo sampling of uncertainty in diets and other key parameters. The MICE model was by design limited to a narrow taxonomic scope and simple representations of forage effects on predators, but this simplicity facilitated $1000 \mathrm{yr}$ projections of predators and forage fish under detailed representation of harvest policies, and exploration of 23 aspects of parameter and structural uncertainty. The Atlantis model is limited in terms of replicates by slow simulation times (days), but it complemented the other approaches by including a broad representation of the whole food web. Atlantis and Ecopath identified additional species that might be included in future MICE (e.g. dolphins and large flatfish [halibut] both decline in the Atlantis model at moderate levels of sardine abundance, and in Ecopath have diets consisting of $8-22 \%$ sardine + anchovy). Other bird groups also declined with reductions in sardine in Atlantis, consistent with an understanding of seabirds as sensitive indicators of ecosystem status (Piatt et al. 2007), and this suggests that additional focused modeling efforts via MICE or other frameworks should be considered. Overall, we agree with Fulton et al. (2015) that in this collaborative context, a suite of models is necessary, including simple models that can be deployed rapidly (in our case Ecopath, and from it, calculation of the PREP and SURF indices).

\subsection{Next steps}

Multi-model inference is often assumed to involve models with similar outputs (e.g. hurricane tracks), but in practice, the present generation of marine ecosystem models differ enough in their structure that careful consideration needs to be given to their common currencies, i.e. putting results in a framework that can be generalized despite model differences. In the future, multi-model inference will benefit from the establishment of standard practices regarding outputs, currencies, and pre-defined schemes for aggregating or comparing over scales of time and space, facilitating synthesis such as ensemble model averaging (e.g. Ianelli et al. 2016). At present, the MICE is best suited to approaches such as ensemble model averaging: it is dynamic (unlike Ecopath) and therefore a likelihood can be calculated based on fits to observed time series data, and its run time is fast enough (unlike Atlantis) that model parameters can be estimated from these data. Nonetheless, even slow-running Atlantis simulations and other dynamic models can be compared against standardized data sets (e.g. time series of predator and prey abun- 
dance) to evaluate model fit to data (see Atlantis examples such as Nyamweya et al. 2016, Olsen et al. 2016). Model fit, for instance in a MICE, can be expressed as the probability of the model given the data, which can be used to weight models for prediction (Ianelli et al. 2016).

Our efforts and those of others presenting at the 2017 ICES/PICES Symposium on Drivers of Dynamics of Small Pelagic Fish Resources suggest additional approaches that are needed if an EBFM toolbox is to focus on small pelagic fish in the California Current. These should include more refined modeling of the energetics, diet needs, and behavior of central-place foragers such as marine mammals and birds (Bertrand et al. 2012, 2014), for instance via individual-based models (Fiechter et al. 2016) or energetics-based movement models (Boyd et al. 2014). The MICE and Atlantis models here include only a crude representation of space, and improvements are necessary to understand the foraging needs of these predators and to evaluate spatial or temporal management options. Socio-economic considerations must also be better addressed, including socio-cultural benefits (Plagányi et al. 2013) that can be linked to standard fisheries management performance metrics. Additionally, changes in sardine catches can be understood in the context of the vulnerability of the human communities that harvest them, for instance via community social vulnerability indices (Jacob et al. 2010, Jepson \& Colburn 2013). Inclusion of such social and economic 'bottom lines' alongside the traditional ecological endpoints is increasingly found in EBFM and ecosystem-based management (EBM) as more holistic constructs of marine ecosystems are developed and incorporated into management objectives (Fletcher et al. 2010). Smith et al. (2007) described the range of approaches needed within an EBFM toolbox, including models that vary in scope from single species, to ecosystems, to full socio-economics. Here we began with a singlespecies sardine model that evolved into the MICE, and extended to full ecosystem Ecopath and Atlantis models, but we have not yet fully included the socioeconomic aspects of the sardine fishery.

Acknowledgements. This work was undertaken as part of the Ocean Modeling Forum and the California Current Integrated Ecosystem Assessment. Richard Parrish (NMFS, retired) provided input and manuscripts related to sardine and anchovy life history and ecology. We thank Chris Harvey and Mary Hunsicker, 3 anonymous reviewers, and the editor for comments on the manuscript. The Ocean Modeling Forum and T.B.F. were supported by the David and Lucile Packard Foundation. Atlantis model development benefited greatly from a grant from the National Oceanic and Atmospheric Administration (NOAA) Ocean Acidification Program and National Centers for Coastal Ocean Science. T.E.E. was supported by the Pew Marine Conservation Fellows program. K.F.J. was partially supported by a grant from Washington Sea Grant, University of Washington, pursuant to NOAA Award No. NA14OAR4170078. W.J.S. was supported by the Pew Charitable Trust and National Fish and Wildlife Foundation. Contributing support for this work was provided by NOAA's Integrated Ecosystem Assessment (IEA) Program. This paper is NOAA IEA program contribution \#2017_3.

\section{LITERATURE CITED}

Abraham CL, Sydeman WJ (2006) Prey-switching by Cassin's auklet Ptychoramphus aleuticus reveals seasonal climate-related cycles of Euphausia pacifica and Thysanoessa spinifera. Mar Ecol Prog Ser 313:271-283

A'mar ZT, Punt AE, Dorn MW (2009) The impact of regime shifts on the performance of management strategies for the Gulf of Alaska walleye pollock (Theragra chalcogramma) fishery. Can J Fish Aquat Sci 66:2222-2242

Baumgartner TR, Soutar A, Ferreira-Bartrina V (1992) Reconstruction of the history of Pacific sardine and northern anchovy populations over the past two millennia from sediments of the Santa Barbara Basin, California. CalCOFI Rep 33:24-40

* Bertrand S, Joo R, Arbulu Smet C, Tremblay Y, Barbraud C, Weimerskirch H (2012) Local depletion by a fishery can affect seabird foraging. J Appl Ecol 49:1168-1177

* Bertrand A, Grados D, Colas F, Bertrand S and others (2014) Broad impacts of fine-scale dynamics on seascape structure from zooplankton to seabirds. Nat Commun 5:5239

*Boyd C, Punt AE, Weimerskirch H, Bertrand S (2014) Movement models provide insights into variation in the foraging effort of central place foragers. Ecol Modell 286: $13-25$

* Checkley DM, Asch RG, Rykaczewski RR (2017) Climate, anchovy, and sardine. Annu Rev Mar Sci 9:469-493

Cheung WW, Brodeur RD, Okey TA, Pauly D (2015) Projecting future changes in distributions of pelagic fish species of Northeast Pacific shelf seas. Prog Oceanogr 130:19-31

Christensen V, Maclean J (eds) (2011) Ecosystem approaches to fisheries: a global perspective. Cambridge University Press, Cambridge

Christensen V, Walters CJ (2004) Ecopath with Ecosim: methods, capabilities and limitations. Ecol Modell 172: 109-139

Collie JS, Botsford LW, Hastings A, Kaplan IC and others (2016) Ecosystem models for fisheries management: finding the sweet spot. Fish Fish 17:101-125

* Cury PM, Boyd IL, Bonhommeau S, Anker-Nilssen T and others (2011) Global seabird response to forage fish depletion - one-third for the birds. Science 334:1703-1706

Essington TE, Plagányi ÉE (2014) Pitfalls and guidelines for 'recycling' models for ecosystem-based fisheries management: evaluating model suitability for forage fish fisheries. ICES J Mar Sci 71:118-127

Fiechter J, Huckstadt LA, Rose KA, Costa DP (2016) A fully coupled ecosystem model to predict the foraging ecology of apex predators in the California Current. Mar Ecol Prog Ser 556:273-285 
Field JC (2004) Application of ecosystem-based fishery management approaches in the northern California Current. $\mathrm{PhD}$ thesis, University of Washington

Field JC, Francis RC, Aydin K (2006) Top-down modeling and bottom-up dynamics: linking a fisheries-based ecosystem model with climate hypotheses in the northern California Current. Prog Oceanogr 68:238-270

Fletcher WJ, Shaw J, Metcalf SJ, Gaughan DJ (2010) An ecosystem based fisheries management framework: the efficient, regional-level planning tool for management agencies. Mar Policy 34:1226-1238

Forrest RE, Savina M, Fulton EA, Pitcher TJ (2015) Do marine ecosystem models give consistent policy evaluations? A comparison of Atlantis and Ecosim. Fish Res 167: 293-312

Fulton EA, Smith AD, Johnson CR (2003a) Mortality and predation in ecosystem models: Is it important how these are expressed? Ecol Modell 169:157-178

Fulton EA, Smith ADM, Johnson CR (2003b) Effect of complexity on marine ecosystem models. Mar Ecol Prog Ser 253:1-16

Fulton EA, Link JS, Kaplan IC, Savina-Rolland M and others (2011) Lessons in modelling and management of marine ecosystems: the Atlantis experience. Fish Fish 12: 171-188

Fulton EA, Boschetti F, Sporcic M, Jones T and others (2015) A multi-model approach to engaging stakeholder and modellers in complex environmental problems. Environ Sci Policy 48:44-56

Gårdmark A, Lindegren M, Neuenfeldt S, Blenckner T and others (2013) Biological ensemble modeling to evaluate potential futures of living marine resources. Ecol Appl 23:742-754

Henry S (2015) Agenda item G.3.a: USFWS report. In: June 2015 briefing book. Pacific Fishery Management Council, Portland, OR. www.pcouncil.org/wp-content/uploads/ 2015/05/G3a_USFWS_Rpt_JUN2015BB.pdf

Hill KT, Crone PR, Dorval E, Macewicz BJ (2015) Assessment of the Pacific sardine resource in 2015 for USA management in 2015-16. Pacific Fishery Management Council, Portland, OR. www.pcouncil.org/wp-content/ uploads/2015/03/G1a_FullSardine_Assessment_E-ONLY_ APR2015BB.pdf

Holsman KK, Ianelli J, Aydin K, Punt AE, Moffitt EA (2016) A comparison of fisheries biological reference points estimated from temperature-specific multi-species and single-species climate-enhanced stock assessment models. Deep Sea Res II 134:360-378

Hurtado-Ferro F, Punt AE (2014) Revised analyses related to Pacific sardine harvest parameters. Pacific Fishery Management Council, Portland, OR. www.pcouncil.org/ wp-content/uploads/I1b_ATT1_REVISED_ANALYSIS_ SARDINE_HRVST_PARMTRS_MAR2014BB.pdf

Ianelli J, Holsman KK, Punt AE, Aydin K (2016) Multi-model inference for incorporating trophic and climate uncertainty into stock assessments. Deep Sea Res II 134: 379-389

Jacob S, Weeks P, Blount BG, Jepson M (2010) Exploring fishing dependence in gulf coast communities. Mar Policy 34:1307-1314

Jacobsen NS, Essington TE, Andersen KH (2016) Comparing model predictions for ecosystem-based management 1. Can J Fish Aquat Sci 73:666-676

Jepson M, Colburn LL (2013) Development of social indicators of fishing community vulnerability and resilience in the US southeast and northeast regions. NOAA Tech Memo NMFS-FSPO-129

Kaplan IC, Brown CJ, Fulton EA, Gray IA, Field JC, Smith ADM (2013) Impacts of depleting forage species in the California Current. Environ Conserv 40:380-393

Kaplan IC, Koehn LE, Hodgson EE, Marshall KN, Essington TE (2017) Modeling food web effects of low sardine and anchovy abundance in the California Current. Ecol Modell 359:1-24

Koehn LE, Essington TE, Marshall KN, Kaplan IC, Sydeman WJ, Szoboszlai AI, Thayer JA (2016) Developing a high taxonomic resolution food web model of the California Current ecosystem to assess the trophic position of forage fish and their predators. Ecol Modell 335:87-100

Link JS, Ihde TF, Townsend HM, Osgood KE and others (2010) Report of the 2nd National Ecosystem Modeling Workshop (NEMoW II): bridging the credibility gap dealing with uncertainty in ecosystem models. NOAA Tech Memo NMFS-F/SPO 102

* Link JS, Ihde TF, Harvey CJ, Gaichas SK and others (2012) Dealing with uncertainty in ecosystem models: the paradox of use for living marine resource management. Prog Oceanogr 102:102-114

MacCall A (1990) Dynamic geography of marine fish populations. Washington Sea Grant Program, Seattle, WA

MacCall AD (2009) Mechanisms of low-frequency fluctuations in sardine and anchovy populations. In: Checkley D, Alheit J, Oozeki Y, Roy C (eds) Climate change and small pelagic fish. Cambridge University Press, Cambridge, p 285-299

MacCall AD, Sydeman WJ, Davison PC, Thayer JA (2016) Recent collapse of northern anchovy biomass off California. Fish Res 175:87-94

Marasco RJ, Goodman D, Grimes CB, Lawson PW, Punt AE, Quinn TJ II (2007) Ecosystem-based fisheries management: some practical suggestions. Can J Fish Aquat Sci 64:928-939

Marine Stewardship Council (2014) Fisheries standard. London. www.msc.org/documents/scheme-documents/ fisheries-certification-scheme-documents/fisheriescertification-scheme-documents\#standard

* Marshall KN, Kaplan IC, Hodgson EE, Hermann AJ and others (2017) Risks of ocean acidification in the California Current food web and fisheries: ecosystem model projections. Glob Change Biol 23:1525-1539

*McClatchie S, Field J, Thompson AR, Gerrodette T and others (2016) Food limitation of sea lion pups and the decline of forage off central and southern California. R Soc Open Sci 3:150628

McClatchie S, Hendy IL, Thompson AR, Watson W (2017) Collapse and recovery of forage fish populations prior to commercial exploitation. Geophys Res Lett 44:18771885

Miller TW, Brodeur RD, Rau G, Omori K (2010) Prey dominance shapes trophic structure of the northern California Current pelagic food web: evidence from stable isotopes and diet analysis. Mar Ecol Prog Ser 420:15-26

Neuenfeldt S (2014) Biological ensemble modelling in the Baltic Sea. In: Report of the 3rd National Ecosystem Modeling Workshop (NEMoW 3): mingling models for marine resource management-multiple model inference. NOAA Tech Memo NMFS-F/SPO 149, p 68

*Nyamweya C, Sturludottir E, Tomasson T, Fulton EA, Taabu-Munyaho A, Njiru M, Stefansson G (2016) Exploring Lake Victoria ecosystem functioning using the 
Atlantis modeling framework. Environ Model Softw 86: 158-167

* Olsen E, Fay G, Gaichas S, Gamble R, Lucey S, Link JS (2016) Ecosystem model skill assessment. Yes we can! PLOS ONE 11:e0146467

Pacific Fishery Management Council (1978) Fishery management plan for northern anchovy. Pacific Fishery Management Council, Portland, OR

Pacific Fishery Management Council (2013) Terms of reference and report of the Pacific Sardine Harvest Parameters Workshop. Pacific Fishery Management Council, Portland, OR, p 19

Patrick WS, Link JS (2015) Myths that continue to impede progress in ecosystem-based fisheries management. Fisheries 40:155-160

Payne MR, Barange M, Cheung WWL, MacKenzie BR and others (2016) Uncertainties in projecting climate-change impacts in marine ecosystems. ICES J Mar Sci 73: 1272-1282

Piatt JF, Sydeman WJ, Wiese F (2007) Introduction: seabirds as indicators of marine ecosystems. Mar Ecol Prog Ser 352:199-204

Pikitch EK, Santora C, Babcock EA, Bakun A and others (2004) Ecosystem-based fishery management. Science 305:346-347

Pikitch EK, Boersma PD, Boyd IL, Conover DO and others (2012) Little fish, big impact: managing a crucial link in ocean food webs. Lenfest Ocean Program, Washington, DC. www.lenfestocean.org/en/news-and-publications/ published-paper/little-fish-big-impact-a-report-from-thelenfest-forage-fish-task-force

Pikitch EK, Rountos KJ, Essington TE, Santora C and others (2014) The global contribution of forage fish to marine fisheries and ecosystems. Fish Fish 15:43-64

Pinnegar JK, Blanchard JL, Mackinson S, Scott RD, Duplisea DE (2005) Aggregation and removal of weak-links in food-web models: system stability and recovery from disturbance. Ecol Modell 184:229-248

Plagányi ÉE (2007) Models for an ecosystem approach to fisheries. FAO, Rome

Plagányi ÉE, Essington TE (2014) When the SURFs up, forage fish are key. Fish Res 159:68-74

Plagányi ÉE, van Putten I, Hutton T, Deng RA and others (2013) Integrating indigenous livelihood and lifestyle objectives in managing a natural resource. Proc Natl Acad Sci USA 110:3639-3644

Plagányi É, Punt AE, Hillary R, Morello EB and others (2014) Models of intermediate complexity for ecosystem assessment to support tactical management decisions in fisheries and conservation. Fish Fish 15:1-22

Punt AE, MacCall AD, Essington TE, Francis TB and others

Editorial responsibility: Verena Trenkel (Guest Editor),

Nantes, France
(2016) Exploring the implications of the harvest control rule for Pacific sardine, accounting for predator dynamics: a MICE model. Ecol Modell 337:79-95

* Rose K, Allen JI, Artioli Y, Barange M and others (2010) End-to-end models for the analysis of marine ecosystems: challenges, issues, and next steps. Mar Coast Fish $2: 115-130$

* Ruzicka JJ, Brodeur RD, Emmett RL, Steele JH and others (2012) Interannual variability in the Northern California Current food web structure: changes in energy flow pathways and the role of forage fish, euphausiids, and jellyfish. Prog Oceanogr 102:19-41

Smith ADM, Fulton EJ, Hobday AJ, Smith DC, Shoulder P (2007) Scientific tools to support the practical implementation of ecosystem-based fisheries management. ICES J Mar Sci 64:633-639

* Smith AD, Brown CJ, Bulman CM, Fulton EA and others (2011) Impacts of fishing low-trophic level species on marine ecosystems. Science 333:1147-1150

* Sydeman WJ, Hobson KA, Pyle P, McLaren EB (1997) Trophic relationships among seabirds in central California: combined stable isotope and conventional dietary approach. Condor 99:327-336

Szoboszlai AI, Thayer JA, Wood SA, Sydeman WJ, Koehn LE (2015) Forage species in predator diets: synthesis of data from the California Current. Ecol Inform 29:45-56

Thayer JA, MacCall AD, Sydeman WJ, Davison PC (2017) California anchovy population remains low, 2012-2016. CalCOFI Rep 58:1-8

* Thorpe RB, Le Quesne WJF, Luxford F, Collie JS, Jennings $S$ (2015) Evaluation and management implications of uncertainty in a multispecies size-structured model of population and community responses to fishing. Methods Ecol Evol 6:49-58

* Travers M, Shin YJ, Jennings S, Cury P (2007) Towards endto-end models for investigating the effects of climate and fishing in marine ecosystems. Prog Oceanogr 75:751-770

*Walters C, Christensen V, Fulton B, Smith ADM, Hilborn R (2016) Predictions from simple predator-prey theory about impacts of harvesting forage fishes. Ecol Modell 337:272-280

*Woodworth-Jefcoats PA, Polovina JJ, Howell EA, Blanchard JL (2015) Two takes on the ecosystem impacts of climate change and fishing: comparing a size-based and a species-based ecosystem model in the central North Pacific. Prog Oceanogr 138:533-545

Zwolinski JP, Demer DA, Macewicz BJ, Cutter GR and others (2017) Distribution, biomass, and demography of the central stock of northern anchovy during summer 2016, estimated from acoustic-trawl sampling. Southwest Fisheries Science Center. NOAA-TM-NMFS-SWFSC-572

Submitted: June 19, 2017; Accepted: Jan 29, 2018

Proofs received from author(s): March 22, 2018 